\title{
A review on the geotechnical and engineering characteristics of marine clay and the modern methods of improvements
}

\author{
Mohammed Ali Mohammed Al-Bared a and Aminaton Marto a,b,* \\ a Soft Soil Eng. Research Group, Department of Geotechnics and Transportation, Faculty of Civil Engineering, Universiti Teknologi Malaysia, \\ 81310 UTM Johor Bahru, Johor, Malaysia \\ b Department of Environmental Engineering \& Green Technology, Malaysia-Japan International Institute of Technology, Universiti Teknologi \\ Malaysia, 54100 Kuala Lumpur, Malaysia \\ * Corresponding author: aminaton@utm.my
}

\section{Article history}

Received 19 November 2017

Accepted 6 December 2017

\begin{abstract}
Marine clay is a soft soil that could be found widely at the coastal and offshore areas. This type of soil is usually associated with high settlement and instability, poor soil properties that are not suitable for engineering requirements and low unconfined compressive strength of less than $20 \mathrm{kPa}$. Considerable failure could occur even with light loads and it shows flat or featureless surface. This kind of soil is considered as problematic due to the existence of high moisture content and usually exists as slurry with noticeable percentage of expandable clay minerals. In this paper, the geotechnical, micro-structure and engineering properties of marine clay are thoroughly reviewed and discussed. The properties include moisture content, particle size distribution, specific gravity, Atterberg limits, mineral compositions and shear strength. Moreover, due to the increasing demand of construction at coastal and offshore areas involving the marine clay, many attempts have been made to stabilize this kind of soil in order to solve the geotechnical related problems. Some of the common stabilization methods used to improve the properties of marine clay such as cement grouting, chemical additives and some environmental friendly additives are discussed. In long term, marine clay treatment using cement was found to be the best method. In addition, this paper serves as a guideline for the design and construction of projects on marine soils.
\end{abstract}

Keywords: Marine clay, index properties, shear strength, soil stabilization

\section{INTRODUCTION}

Marine clay is a type of soil that is largely exists at the coastal corridors, low lands and offshore areas as well as other parts of the earth. It can be described as soft sensitive soil that is always associated with high settlement and high instability, poor soil properties that are not suitable for engineering requirements, uncertainty of performance, low unconfined compressive strength of between 25 to $50 \mathrm{kPa}$ and flat or featureless surface (Ali and Alsamaraee, 2013). In addition, marine clay usually consists of soil minerals such as chlorite, kaolinite, montmorillonite and illite, and other stone minerals such as quartz and feldspar that are all bonded together by the presence of organic matters (Rahman et al., 2013; Yunus et al., 2015). Marine clay also exists at the bottom of water bodies and reservoirs such as rivers, harbours and channels. This kind of marine clay is called degraded marine clay and it is usually removed by excavation for the purpose of enlarging the rivers, controlling flood, and access to harbour and port channel. The excavated degraded marine clay is disposed in the environment which ends up as a waste (Shahri and Chan, 2015). Lee et al. (2016) investigated the marine clay at one construction site in Kedah, Malaysia and found that the soil has the undrained shear strength of less than $25 \mathrm{kPa}$. It is highly challengeable to work with marine clay soil due to its great influence by moisture content. It swells when the moisture increased and shrinks when decreased (Pakir et al., 2014).
Moreover, there is a significant difference between the saturated marine clay and any other moist soils in terms of engineering properties. Marine clays are greatly susceptible to changes in the moisture content and when exist beneath pavements or foundations, they are unstable and their performance is often unpredictable (Yunus et al., 2015). Therefore, marine clay should be treated and its properties need to be improved before it is suitable to become the foundation for construction projects or a subgrade for pavements of roads and highways (Marto et al., 2015). Marine clay has been described by Rao et al. (2011) as the soil that has a natural moisture content of higher than its liquid limit. According to Bushra and Robinson (2009), high compressibility and low shear strength are the reason for most of the problems encountered when projects are constructed on marine clay deposits. In addition, Rao and Mathew (1996) defined marine clay deposits as loose sediments that are formed with high void ratio and are highly sensitive to stress system and water content. Tanaka et al. (2001) studied the minerals of Singapore marine clay and compared it with samples obtained from Japan and Bangkok. Kaolinite was the main mineral of the Singapore marine clay whilst smectite was the main mineral for Bangkok and Japan clays. When occurred above water table or in dry condition, the marine clay is very strong but it loses its strength even when partially wetted. Cracks appear on its surface when dried and the cracks width is almost 250-500 $\mathrm{mm}$ with $1 \mathrm{~m}$ depth. Moderate swelling is observed when moisture come in contact because marine clay contains minerals that has expanding behaviour (Rao et al., 2012). 
Hence, studying marine clay extensively and providing detailed review about it would serve as a platform to understand its engineering characteristics and behaviour in order to guide future engineers and contractors on its performance during construction. Since there is no available paper that particularly reviewed the geotechnical properties of marine clay, this paper attempts to show a comprehensive data with respect to marine clay properties. Modern stabilization methods adopted by some researchers that made contribution to the stability of marine clay are also illustrated and discussed. Moreover, recommendations and suggestions on the best improvement methods that suits the marine clay as well as environmentally friendly stabilizers are described.

\section{PHYSICAL PROPERTIES OF MARINE CLAY}

The physical properties of marine clay play an important role in determining the strength and the stability of marine deposits. The main index properties that usually affect the strength and compressibility of marine clay are particle size distribution, liquid limit, plastic limit, plasticity index, moisture content, specific gravity, organic content, shrinkage limit and mineral composition. In addition, the depth from which the marine clay is obtained and the age of the soil also influence the index properties and usually decrease with higher age and depth. Therefore, the index properties of marine clay are investigated and evaluated carefully.

\section{Index properties of marine clay}

Marine clay is highly compressible and swellable soil which is usually found in a natural moisture content that is higher than its liquid limit. The natural moisture content of marine clay reviewed in this paper varied from $39 \%$ to about $175 \%$ depending on the depth and location from which the soil was obtained. Fig. 1 illustrated comparative analysis between the natural moisture content and the Atterberg limits of marine clay. It is clearly observed that the natural moisture content of marine clay is higher than its liquid limit in most of the studies conducted in different areas. As a result, it is the kind of soil that has the tenancy to absorb much quantity of water until it loses its shape. Thus, marine clay often found in a slurry form.

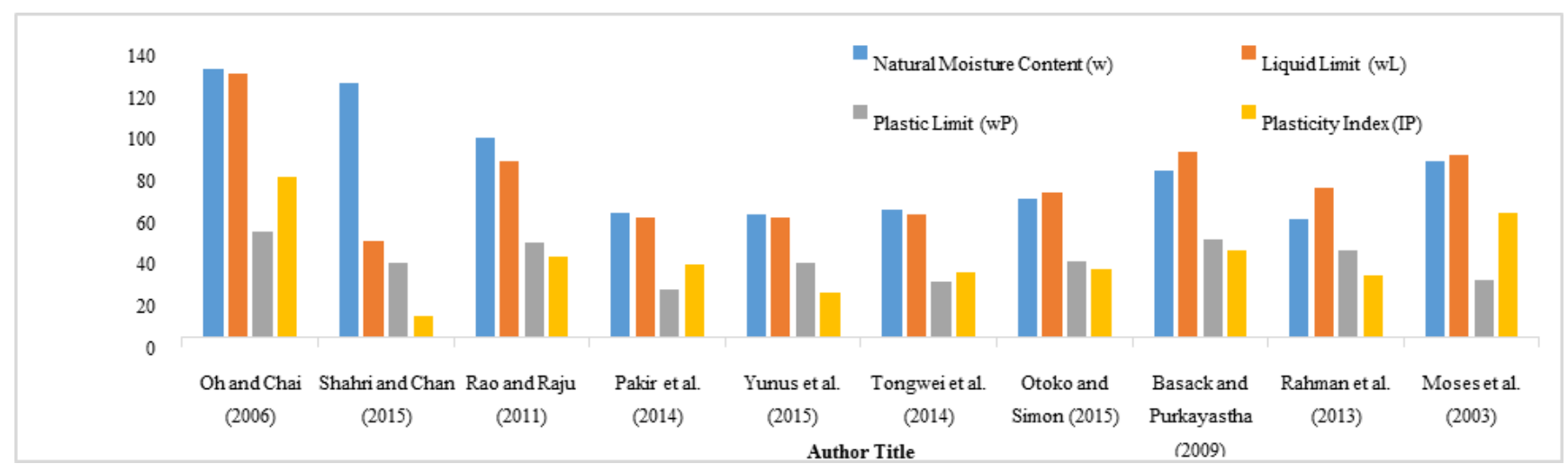

Fig. 1 Natural moisture content and Atterberg limits as reported by prominent authors.

Egashira and Ohtsubo (1982) conducted a study on marine clay and several samples obtained from Japan. All the samples obtained were reported to have a moisture content that was more than its liquid limit. Arulrajah and Bo (2008) studied the engineering characteristics of Singaporean marine clay obtained from boreholes in Changi. The liquid limit for the upper layer of marine clay was between $80 \%$ and $95 \%$ while the plastic limit was between $20 \%$ and $28 \%$. The moisture content was recorded to be between $70-88 \%$ which is almost the same value with the liquid limit. In addition, the lower layer of marine clay had a liquid limit of between $65 \%$ and $90 \%$ and plastic limit of between $20 \%$ and $30 \%$, respectively. Moreover, Kang et al. (2016) studied dredged marine clay collected from four different locations in Japan to be treated with cement. However, the index properties of dredge marine clay were evaluated. The liquid limit of all the collected samples varied from $61.2 \%$ to $107.6 \%$ while the plastic limit of all samples varied from $15.5 \%$ to $35.4 \%$.

Table 1 demonstrated a comparison between the physical properties of marine clay from various locations, in particular, Malaysian marine clay. In terms of particle size distribution, fine particles (less than $0.002 \mathrm{~mm}$ ) were the majority of marine clay for all the selected studies. All the studies had more than $40 \%$ fine particles except two studies conducted in Malaysia by Rahman et al. (2013) and Shahri and Chan (2015), had a fine contents of 24 and $26 \%$, respectively. The higher percentages of fine particles is because marine clay is deposited over decades of time. Moreover, Silt particles were the second major particles followed by sand. Sand particles were in the range of $0-30 \%$ of all the studies. Gravel particles were zero percentage for all the studies except 4 studies obtained from Malaysia. Those studies were conducted in Perak, Melaka, Kelantan and Johor and the percentage of gravel particles were $10,3,5$ and $2 \%$, respectively. Meanwhile, the natural moisture content was more than $39 \%$ of all the selected studies and that indicated a flowing condition of marine clay. The high moisture content that is found to be more than $167 \%$ in some of the studies is due to the tenancy of marine clay to absorb more water than it needs until it loses its shape. However, those studies that had a moisture content of more than $80 \%$, marine clay will be in slurry form.

In addition, specific gravity which is defined as the ratio of the mass of soil to the mass of water ranged from 2.15 to 2.72 . Besides, the liquid limit was more than $50 \%$ and less than $127 \%$ while the plastic limit was in the range of 18 to $94 \%$. The plasticity index was in the range of $11 \%$ to $77 \%$ which indicates very high plasticity for some of the studies. The higher plastic is the soil, the poor engineering and geotechnical characteristics. Moreover, the shrinkage limit was in the range of 13 to $18 \%$ and the organic contents were in the range of 2 to $7 \%$. As a result to the above mentioned characteristics, marine clay deposits always considered problematic and generally possess poor to very weak engineering behaviour compared to other kind of soils. When soft soil is found in high moisture content and high plasticity, this assure weak performance as water is considered enemy of soil. However, marine clay is favourable to water as mentioned earlier and its plasticity index is high.

Furthermore, Table 2 is discussing the physical index properties of marine clay in Malaysia at the North West Coast and Central West Coast areas. It is observed from Table 2 that the moisture content at the North West Coast varies from 15 to $112 \%$ for the three listed studies. In addition, the liquid limit varies from 19 to $150 \%$ while the plastic limit was in the range of $15-56 \%$. Plasticity index was as minimum as $13 \%$ at Butterworth and as high as $81 \%$ at SE Coast of Penang Island. In comparison, the moisture content at Klang area varies from $20 \%$ to $175 \%$ which was significantly higher than those reported at the North West Coast. The unit weight and specific gravity of marine clay were in the range of $13.2-16.8$ and $2.45-2.65$, respectively. The liquid limit and plastic limit were higher than those reported at North West Coast. It is notable that marine clay at North West Coast has index properties that is better than the ones found at Central West Coast area. 
Table 1 Physical and index properties of some studies on marine clay.

\begin{tabular}{|c|c|c|c|c|c|c|c|c|c|c|c|c|}
\hline \multirow{2}{*}{ Reference } & \multirow{2}{*}{ Location } & \multicolumn{4}{|c|}{ Particle Size Distribution } & \multirow{2}{*}{$\begin{array}{l}\text { Natural } \\
\text { Moisture } \\
\text { Content } \\
\text { (w) }\end{array}$} & \multirow{2}{*}{$\begin{array}{c}\text { Specific } \\
\text { Gravity } \\
\left(G_{s}\right)\end{array}$} & \multirow{2}{*}{$\begin{array}{c}\text { Liquid } \\
\text { Limit } \\
\left(w_{L}\right)\end{array}$} & \multirow{2}{*}{$\begin{array}{c}\text { Plastic } \\
\text { Limit } \\
\left(w_{P}\right)\end{array}$} & \multirow{2}{*}{$\begin{array}{l}\text { Plasticity } \\
\text { Index (IP) }\end{array}$} & \multirow{2}{*}{$\begin{array}{c}\text { Shrinkage } \\
\text { Limit }\end{array}$} & \multirow[t]{2}{*}{$\begin{array}{l}\text { Organic } \\
\text { Content }\end{array}$} \\
\hline & & $\begin{array}{l}\text { Gra } \\
\text { vel }\end{array}$ & Sand & Silt & Clay & & & & & & & \\
\hline $\begin{array}{l}\text { Moses et al. } \\
(2003)\end{array}$ & Singapore & $0 \%$ & $0 \%$ & $46 \%$ & $54 \%$ & $\begin{array}{l}80- \\
85 \%\end{array}$ & - & $88 \%$ & $28 \%$ & 60 & - & - \\
\hline $\begin{array}{l}\text { Oh and Chai } \\
\quad(2006)\end{array}$ & Malaysia & - & - & - & $40 \%$ & $\begin{array}{c}39 \% \text { to } \\
129 \%\end{array}$ & $\begin{array}{c}2.6 \text { to } \\
2.7\end{array}$ & $\begin{array}{c}50 \% \\
\text { to } \\
127 \%\end{array}$ & $\begin{array}{c}18 \% \text { to } \\
51 \%\end{array}$ & 19 to 77 & - & - \\
\hline $\begin{array}{l}\text { Bushra and } \\
\text { Robinson } \\
(2009) \\
\text { Basack and }\end{array}$ & India & $0 \%$ & $9 \%$ & $47 \%$ & $44 \%$ & $45 \%$ & 2.6 & $56 \%$ & $25 \%$ & 31 & - & $5 \%$ \\
\hline $\begin{array}{l}\text { Purkayastha } \\
(2009)\end{array}$ & India & $0 \%$ & $14 \%$ & $27 \%$ & $59 \%$ & $80 \%$ & 2.6 & $89 \%$ & $47 \%$ & 42 & $16 \%$ & - \\
\hline $\begin{array}{l}\text { Rahman et } \\
\text { al. (2013) } \\
\text { Otoko and }\end{array}$ & Malaysia & $0 \%$ & $19 \%$ & $57 \%$ & $24 \%$ & $56 \%$ & 2.6 & $72 \%$ & $42 \%$ & 30 & - & $2 \%$ \\
\hline $\begin{array}{c}\text { Blessing } \\
(2014)\end{array}$ & Nigeria & $0 \%$ & $18 \%$ & $40 \%$ & $42 \%$ & $89 \%$ & 2.2 & $118 \%$ & $46 \%$ & 72 & $18 \%$ & $7 \%$ \\
\hline $\begin{array}{l}\text { Tongwei et } \\
\text { al. (2014) }\end{array}$ & India & $0 \%$ & $13 \%$ & $23 \%$ & $64 \%$ & $96 \%$ & 2.4 & $85 \%$ & $46 \%$ & 39 & $13 \%$ & - \\
\hline $\begin{array}{l}\text { Tongwei et } \\
\text { al. (2014) } \\
\text { Izabel and }\end{array}$ & China & $0 \%$ & $3 \%$ & $44 \%$ & $54 \%$ & $62 \%$ & - & $59 \%$ & $27 \%$ & 32 & - & - \\
\hline $\begin{array}{l}\text { Sangeetha } \\
\text { (2014) }\end{array}$ & India & $0 \%$ & $11 \%$ & $49 \%$ & $50 \%$ & - & 2.7 & $71 \%$ & $33 \%$ & 38 & - & - \\
\hline $\begin{array}{l}\text { Pakir et al. } \\
(2014)\end{array}$ & $\begin{array}{l}\text { Malaysia } \\
\text { Johor } \\
\text { Malaysia }\end{array}$ & - & - & - & - & $60 \%$ & 2.6 & $58 \%$ & $23 \%$ & 35 & - & - \\
\hline Chan (2014) & $\begin{array}{l}\text { Lumut } \\
\text { Melaka }\end{array}$ & $\begin{array}{l}0 \% \\
0 \%\end{array}$ & $\begin{array}{l}14 \% \\
9 \%\end{array}$ & $\begin{array}{c}8 \% \\
18 \%\end{array}$ & $\begin{array}{l}75 \% \\
69 \%\end{array}$ & $\begin{array}{l}166 \% \\
166 \%\end{array}$ & - & $\begin{array}{l}98 \% \\
54 \%\end{array}$ & $\begin{array}{l}22 \% \\
31 \%\end{array}$ & $\begin{array}{l}76 \\
23\end{array}$ & - & - \\
\hline $\begin{array}{l}\text { Kasim et al. } \\
(2015)\end{array}$ & $\begin{array}{c}\text { Malaysia } \\
\text { Perak }\end{array}$ & $10 \%$ & $30 \%$ & $30 \%$ & $40 \%$ & & 2.6 & $123 \%$ & $94 \%$ & 29 & & \\
\hline $\begin{array}{l}\text { Yunus et al. } \\
(2015) \\
\text { Otoko and }\end{array}$ & $\begin{array}{l}\text { Malaysia } \\
\text { Johor }\end{array}$ & - & - & - & - & $59 \%$ & 2.6 & $58 \%$ & $36 \%$ & 22 & $4 \%$ & - \\
\hline $\begin{array}{l}\text { Simon } \\
(2015)\end{array}$ & $\begin{array}{l}\text { Nigeria } \\
\text { Malaysia }\end{array}$ & $0 \%$ & $19 \%$ & $40 \%$ & $41 \%$ & $67 \%$ & 2.2 & $70 \%$ & $37 \%$ & 33 & $18 \%$ & $7 \%$ \\
\hline $\begin{array}{l}\text { Shahri and } \\
\text { Chan (2015) }\end{array}$ & $\begin{array}{l}\text { Perak } \\
\text { Melaka } \\
\text { Kelantan } \\
\text { Johor }\end{array}$ & $\begin{array}{l}3 \% \\
3 \% \\
5 \% \\
2 \%\end{array}$ & \begin{tabular}{|l|}
$15 \%$ \\
$9 \%$ \\
$20 \%$ \\
$18 \%$
\end{tabular} & \begin{tabular}{|c|}
$4 \%$ \\
$20 \%$ \\
$15 \%$ \\
$54 \%$
\end{tabular} & $\begin{array}{l}78 \% \\
68 \% \\
60 \% \\
26 \%\end{array}$ & $\begin{array}{c}166 \% \\
146 \% \\
92 \% \\
122 \%\end{array}$ & $\begin{array}{l}2.6 \\
2.6 \\
2.4 \\
2.4\end{array}$ & $\begin{array}{l}96 \% \\
59 \% \\
37 \% \\
46 \%\end{array}$ & $\begin{array}{l}35 \% \\
31 \% \\
26 \% \\
36 \%\end{array}$ & $\begin{array}{l}61 \\
28 \\
11 \\
10\end{array}$ & $\begin{array}{l}- \\
- \\
-\end{array}$ & $\begin{array}{l}- \\
- \\
-\end{array}$ \\
\hline $\begin{array}{l}\text { Prasad } \\
\text { (2016) }\end{array}$ & India & $0 \%$ & $6 \%$ & $28 \%$ & $67 \%$ & - & 2.4 & $73 \%$ & $32 \%$ & 41 & - & - \\
\hline \multirow[t]{2}{*}{$\begin{array}{c}\text { Ahmad and } \\
\text { Harahap } \\
(2016)\end{array}$} & $\begin{array}{l}\text { Malaysia } \\
\text { Sarawak } \\
\text { Sarawak } \\
\text { Sarawak } \\
\text { Sarawak }\end{array}$ & $\begin{array}{l}0 \% \\
0 \% \\
0 \% \\
0 \%\end{array}$ & $\begin{array}{l}12 \% \\
8 \% \\
5 \% \\
5 \%\end{array}$ & $\begin{array}{l}63 \% \\
52 \% \\
47 \% \\
35 \%\end{array}$ & $\begin{array}{l}25 \% \\
40 \% \\
48 \% \\
60 \%\end{array}$ & $\begin{array}{c}24.2 \% \\
\text { To }\end{array}$ & $\begin{array}{l}2.4 \\
\text { To }\end{array}$ & $\begin{array}{l}56 \% \\
55 \% \\
54 \% \\
55 \%\end{array}$ & $\begin{array}{l}33 \% \\
30 \% \\
31 \% \\
36 \%\end{array}$ & $\begin{array}{l}23 \\
25 \\
23 \\
19\end{array}$ & $\begin{array}{l}- \\
- \\
-\end{array}$ & $\begin{array}{l}- \\
- \\
-\end{array}$ \\
\hline & $\begin{array}{c}\text { Peninsular } \\
\text { Malaysia }\end{array}$ & $0 \%$ & $7 \%$ & $46 \%$ & $47 \%$ & $65.2 \%$ & 2.66 & $51 \%$ & $28 \%$ & 23 & - & - \\
\hline
\end{tabular}

Table 2 The geotechnical and index properties of marine clay in Malaysia (After Ramamoorthya, 2007).

\begin{tabular}{|c|c|c|c|c|c|c|}
\hline Location & $\begin{array}{c}\text { Natural } \\
\text { Moisture } \\
\text { Content, } \\
\text { w (\%) }\end{array}$ & $\begin{array}{c}\text { Unit } \\
\text { Weight, } Y \\
\left(\mathrm{kN} / \mathrm{m}^{3}\right)\end{array}$ & $\begin{array}{c}\text { Specific } \\
\text { Gravity, } \\
\text { G }_{\mathrm{s}}\end{array}$ & $\begin{array}{c}\text { Liquid } \\
\text { Limit, } \\
\mathbf{W}_{\mathrm{L}} \\
(\%)\end{array}$ & $\begin{array}{c}\text { Plastic Limit, } \\
w_{\mathrm{p}} \\
(\%)\end{array}$ & $\begin{array}{l}\text { Plasticity } \\
\text { Index, } I_{p}\end{array}$ \\
\hline \multicolumn{7}{|l|}{$\begin{array}{l}\text { NORTH WEST COAST, } \\
\text { PENINSULAR MALAYSIA }\end{array}$} \\
\hline South of Sg Petani & $15-112$ & & & $37-39$ & $15-44$ & $20-62$ \\
\hline Butterworth & $22-101$ & - & - & $19-126$ & $23-56$ & $13-49$ \\
\hline SE Coast of Penang Island & $34-89$ & & & $28-150$ & $22-47$ & $20-81$ \\
\hline \multicolumn{7}{|l|}{$\begin{array}{c}\text { CENTRAL WEST COAST, } \\
\text { PENINSULAR }\end{array}$} \\
\hline MALAYSIA & $50-100$ & 14-16 & & $50-150$ & $30-70$ & $20-80$ \\
\hline Klang & $100-140$ & $13.2-16.8$ & $2.45-2.65$ & $106-142$ & $26-42$ & - \\
\hline & $20-175$ & 14.6-15 & & - & - & - \\
\hline
\end{tabular}




\section{Index properties of marine clay in Malaysia}

Marine clay is largely found in Malaysia due to its tropical climate and its geographical location as a peninsular country. A case study has been selected in order to investigate the index properties of representative Malaysian marine clay. Fig. 2 shows the dredged marine clay that was obtained from a depth of $1-3$ meter below the ground surface. This dredged marine clay was excavated at a development area in Kota Iskandar, Nusajaya, Johor, Malaysia. A lot of research had been conducted to investigate the properties of the soil at the above mentioned area, such as done by Yunus et al (2015). Table 3 illustrates some of the obtained index and mechanical properties of the soil before and after the treatment.

Table 3 Index and mechanical properties of marine clay at Kota Iskandar, Nusajaya, Johor, Malaysia (Pakir et al., 2014; Yunus et al., 2015)

\begin{tabular}{ccc}
\hline Index Properties & $\begin{array}{c}\text { Before } \\
\text { treatment }\end{array}$ & $\begin{array}{c}\text { After } \\
\text { treatment }\end{array}$ \\
\hline Natural moisture content (\%) & 60 & - \\
Specific gravity & 2.62 & - \\
Liquid limit(\%) & 58 & 50 \\
Plastic limit (\%) & 23 & 30 \\
Plasticity index (\%) & 35 & 22 \\
Organic content (\%) & 4.2 & - \\
Optimum moisture content (\%) & 21 & 18 \\
Maximum dry density $\left(\mathrm{kg} / \mathrm{m}^{3}\right)$ & 1600 & 1720 \\
UCS (kPa) & 23 & 91 \\
\hline
\end{tabular}

Since the area containing the marine clay had been decided to be developed, it has been agreed that the marine clay should be dredged out and replaced with stiff soil of better strength and physical properties. The marine clay is quite deep and it will be very costly to replace all with other suitable stiff soil. Hence, current studies in Universiti Teknologi Malaysia (UTM) aimed to find a solution such as obtaining a stabilizing additive that can increase the strength of marine clay and enhance its engineering properties. Marto et al. (2015) used a chemical stabilizer called biomass silicate to treat the marine clay at this area. The treatment resulted in a significant increase in the unconfined compressive strength (UCS) of the soil within just after 7 days of curing. The optimum value of biomass silicate was $15 \%$ at which the UCS value of treated marine clay reached up to $1376 \mathrm{kPa}$ at 28 days curing period. In addition, the plasticity index of the soil was remarkably reduced.

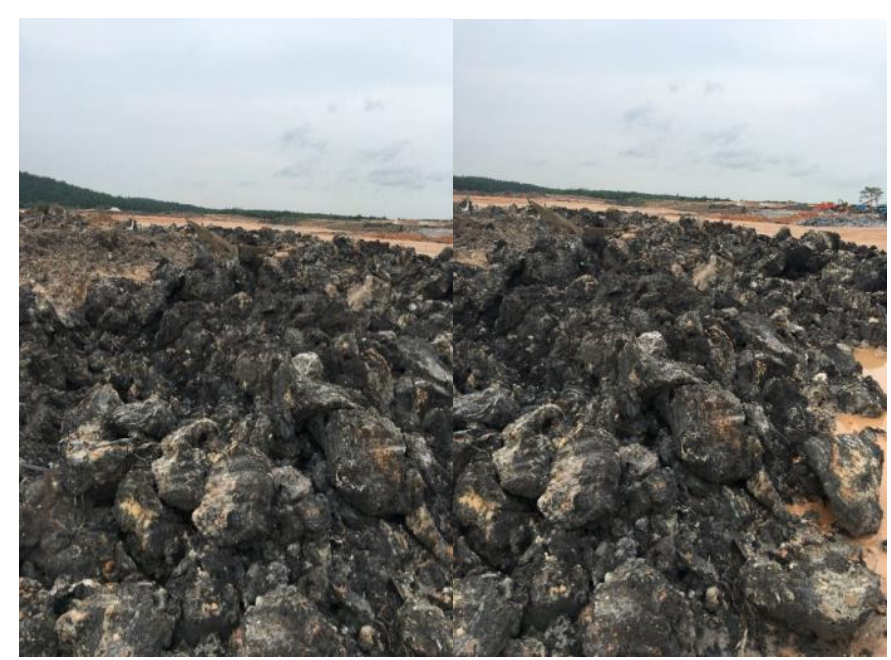

Fig. 2 Dredged marine clay at Nusajaya, Johor obtained from $1-3$ meter depth (Taken by the author).

\section{UNCONFINED COMPRESSIVE STRENGTH}

The unconfined compressive strength (UCS) can be described as the maximum vertical load or stress that the sample can sustain before it collapsed or failed. UCS is one of the most important parameters to be investigated and evaluated when dealing with marine clay or any other kind of soil to observe its shear strength before and after it is improved. Poorly estimated strength of marine clay may results in economical and safety crises when development took place over the area.

\section{Unconfined compressive strength of marine clay}

It is essential to study the strength of marine clay during the prestage of construction in order to come out with the best improvement method that suits the type of project involved. In most cases, the strength of marine clay is extremely low which cannot even stand its self-weight. In addition, marine clay exhibits acceptable strength when it is completely dried, but when water is in contact, marine clay has the tenancy to absorb water more than the amount of its liquid limit. Hence, marine clay is always found in a slurry form that has a negligible strength (Rao et al., 2011). Bo et al. (2015) studied the geotechnical properties of Singapore marine clay. The three layers of clay, i.e. upper soft marine layer, intermediate stiff soil and lower marine clay were investigated. It has been found that the undrained shear strength of the upper soft marine layer varied from 10 to $30 \mathrm{kPa}$ while the undrained shear strength of the lower marine clay layer varied from 30 to $60 \mathrm{kPa}$. The lower layer of marine clay composed of $\mathrm{K}$-feldspar, quartz, muscovite and pyrite that contain chemical elements such as $\mathrm{Al}, \mathrm{Si}, \mathrm{Mg}, \mathrm{K}$ and $\mathrm{Fe}$. Those elements were able to cause cementation bonding within the marine clay particles.

\section{Unconfined compressive strength of marine clay in Malaysia}

Marto et al. (2015) studied the UCS of dredged marine clay collected from Nusajaya, Johor. The UCS of the untreated marine clay was $23 \mathrm{kPa}$ while those treated samples with $15 \%$ Biomass Silica (BS) had strength of $1376 \mathrm{kPa}$. Moreover, Yunus et al. (2015) also conducted a study on the same soil but with different soil additive. The additive used was lime and the UCS of marine clay treated with 9\% lime was $517 \mathrm{kPa}$ at 28 days curing period. Kasim et al. (2015) conducted research on marine clay samples obtained from the state of Perak. BS was used as additive to treat the marine clay. The UCS of the treated samples increased as the amount of additive increased and was $1216 \mathrm{kPa}$ at 28 days curing period. Chong and Kassim (2015) evaluated the strength of marine clay obtained from Pontian, Johor and found that the UCS for untreated samples was $261 \mathrm{kPa}$. When those samples were treated with lime, the UCS value increased to 645 $\mathrm{kPa}$ when cured for 224 days.

\section{MINERAL COMPOSITIONS OF MARINE CLAY}

Marine clay deposits are complex in nature and its engineering behaviour is hardly understood. The properties of marine clay depends mainly on the mineral compositions and micro-structural arrangements of the minerals within the soil. Marine clay has high percentage of clay and therefore may exhibit the appearance of clay minerals that are responsible for the weak characteristics of marine clay. Liu et al. (2011) conducted a research study on the geotechnical properties of marine clay from Lianyungang, China. From the X-ray diffraction (XRD) tests, their results indicated that the main minerals of marine clay are illite and a mixed layer of illite-smectite. Rajasekaran et al. (1999) evaluated the physico-chemical characteristics of marine clay deposits obtained from the coastal region in India. The presence of highly swelling and compressible minerals such as ermiculite, smectite, chlorite, kaolinite and some non-clay minerals such as quartz and feldspar were confirmed by XRD study. They also conducted some fabric studies on the same samples using scanning electron microscopy (SEM) in order to observe the arrangement of the minerals within the marine clay. The results of the fabric studies indicated that minerals were distributed in an open network which created high void ratio. Hence, any construction on the marine clay deposit that contain the earlier mentioned minerals will suffer excessive settlement. In a later study, the mineral compositions of Indian marine clay were investigated by Rajasekaran and Rao (2002) who found that montmorillonite was the 
main mineral with a percentage of $15 \%$. The other mineral compositions were kaolinite, sepiolite, quartz and chloritevermiculite-montmorillonite with a percentage of $9,13,36$ and $27 \%$, respectively. The higher percentage of the expandable clay minerals such as vermiculite and smectite, the lower the strength of marine clay. Furthermore, a research was conducted at Nusajaya, Johor by Yunus et al. (2015) showed that montmorillonite was the main mineral in marine clay. According to Rahman et al. (2013), montmorillonite, kaolinite and illite were the minerals composed within marine clay obtained from Kedah, Malaysia. From the above listed studies, it is clearly noticed that marine clay consist of several highly compressible clay minerals such as vermiculite and chlorite at different percentages. Those minerals are responsible for the compressible and swelling behaviour exhibited by marine clay. Their percentages seems to control the degree of compressibility and swellability of the soil. Moreover, the mineral content in marine clay depends on the depth and location of the sample, aging of deposition etc. Last but not least, montmorillonite is found to be the most influenced clay mineral in marine clay.

\section{IMPROVEMENT TECHNIQUES OF MARINE CLAY}

Marine clay that usually exists in offshore areas will not easily be stabilized using conventional stabilization techniques as it will not be effective due to the wave cyclic behaviour. It is observed that a lot of construction projects involving marine clay tends to excavate, transport and dump the soil in legal or illegal landfills as it is unsuitable for construction. This will create another issue from environmental perspectives. Furthermore, soil improvement is described as an alteration or modification to one or more of the soil properties using various common methods. Soil can be stabilized either chemically using chemical additives, mechanically by compaction, biologically by bacteria, or hydrologically by controlling the temperature. Marine clay is one of those problematic soft soils that has to be improved prior to any construction so as for the soil to be able to stand the imposed load from the structure. The level of stabilization depends greatly on the type of structure to be built and engineering properties of the marine clay. According to Thomas et al. (2002) , historically, engineers and contractors attempted many ways to treat the damages associated with soft soils but it was all based on trial-and-error. Most of the methods used were mechanically stabilizing the soil and a physiochemical treatment was necessary to permanently alter the properties of soft soils. Otoko and Blessing (2014) used cement and lime to improve the strength and the compaction behaviour of marine clay. The unconfined compressive strength was significantly improved and maximum dry density $\left(\rho_{d}, \max \right)$ was increased as the amount of cement or lime increased with a corresponding reduction in the optimum moisture content (wopt), when the soil was compacted. Kiran and Prasad (2016) treated marine clay with $1 \%$ ferric chloride $(\mathrm{FeCl} 3)$ and $20 \%$ quarry dust which resulted in decreasing the liquid limit sufficiently, and noticeably increasing the California Bearing Ratio (CBR) and the load carrying capacity values. Izabel and Sangeetha (2014) tested the suitability of jerofix, i.e. a waste material obtained during the extraction of zink ore to treat marine clay. The addition of jerofix was successfully able to alter all the engineering properties of the soil. UCS and $\rho_{\mathrm{d}}$, max were increased as the amount of jerofix increased while Atterberg limits and $\mathrm{w}_{\mathrm{opt}}$ decreased as the additive increased. The same results were also obtained by Otoko and Simon (2015) but with the used of different additives which were chlorides of magnesium, calcium and sodium additives. Moreover, the by-product of saw dust that is obtained from wood cutting factories was utilized by Rao et al. (2012) together with lime to treat marine soil. The liquid limit and wopt were decreased when about $15 \%$ of saw dust was added and further decreased with the addition of lime while the plastic limit and $\rho_{\mathrm{d}}, \max$ were improved. However, Zhang et al. (2013) reported that the dredged marine soils can be reused as a filler material for land reclamation after being treated with low percentage of cement. The results of previous studies on various chemical additives which includes lime, cement and biomass silica to stabilize marine clay are reviewed and discussed in the following sub-sections.

\section{Lime treated marine clay}

The treatment of marine clay using lime was adopted since 1975 by a lot of researchers which means that lime as additive for soft soil is not new in this area of research. Lime is used to stabilize marine clay due to its fast and reliable characteristics to decrease the sensitivity of changes in stress. Rajasekaran and Rao (2004) used lime to treat marine clay in order to increase its strength to be able to stand more loads. The treated marine clay was obtained from the sea. The optimum amount of lime used was $6 \%$ of the dry weight of soil and falling cone method was adopted to measure the strength. Lime was injected for the deep layers while lime columns were used for the shallow ones. The shear strength of untreated marine clay was 16 $\mathrm{kN} / \mathrm{m}^{2}$ and lime treatment was able to increase the strength 8 to 10 times the untreated one. Although the treatment was done in the presence of sea water but no significant influence of the sea water was encountered. Similarly, Liu et al. (2011) conducted a study on the permeability of lime treated marine clay. The permeability was increased 15-16 times the untreated samples which means that lime can also act as a vertical drain that improve the engineering characteristics of marine clay. Rajasekaran and Rao (2002) continued their research on lime treated marine clay with respect of compressibility. As mentioned earlier, lime was injected into the marine clay slurry and also lime columns were used. Due to the formation of several cementation compounds of soil-lime treatment, the consolidation tests conducted showed a decrease in the compressibility of marine clay of about half to one-third of the value of the untreated one. The compressibility decreased from 0.85 to 0.36 . Although lime was successfully shown to be a good additive to improve strength, compressibility, permeability and all other characteristics of marine clay, there are still problems occurred from the adoption of lime in marine clay stabilization, besides concerning the environmental issues. For instance, Rajasekaran (2005) conducted a review study to investigate the reason of damages and swelling in pavements stabilized by lime or cement. Marine clay treated by lime or cement in an environment enrich with sulphate resulted in the formation of swelling minerals such as ettringite and thaumasite. Therefore, the presence of carbonate and sulphate dissolved acids should be properly investigated before the treatment of marine clay using lime or cement. As discussed above, lime can be a good additive for soft soil to increase its strength and engineering properties. However, lime in its chemical form resulted in several environmental problems when adopted in soft soil stabilization such as ground water contamination.

\section{Cement treated marine clay}

Cement is considered the oldest method for soil stabilization as it was introduced as soil stabilizer in 1960's (Makusa, 2013). Zillianstetra (2009) who studied the Singapore marine clay, treated the soil with cement in two different proportions; 2:1:4 and 5:1:6 of soil, cement and water. The samples were cured for 7 days and tested under triaxial drained and undrained conditions. Samples with 2:1:4 proportion undergo the tests with consolidation pressure of $1500 \mathrm{kPa}$ while those prepared with 5:1:6 proportion were tested under 2000 $\mathrm{kPa}$ consolidation pressure. The results showed that the maximum strength occurred at $1 \%$ and $2 \%$ of the axial strain, respectively during the undrained condition. During the drained condition, Zillianstetra (2009) reported the decreased from the initial volume as the confining pressure was increased. In a different study, Bushra and Robinson (2010) conducted a laboratory investigation in treating the marine clay excavated at $1.5 \mathrm{~m}$ depth from the sea with cement. Cement percentages were 10,15 and $20 \%$ of the dry weight of the soil. Treated samples were cured for 28 days under 100,150 and $200 \mathrm{kPa}$ stresses to represent samples at a depth of 10,15 and $20 \mathrm{~m}$, respectively. Results showed that $15 \%$ of cement was the optimum value at which the strength was maximum at 28 days curing period. The strength was increased under the curing stress for both drained and undrained condition but the drained condition was found to be more effective. The samples cured under undrained condition had an increase in the water content at the end of curing period. As a result, samples with curing stress under drained condition had higher strength. 
According to Xiao and Lee (2016), Singapore marine clay was treated with different proportions of cement and tested under UCS and triaxial tests. The results indicated a significant improvement in all the physical properties of marine clay. The UCS, strain stress behaviour and isotropic compression behaviour were significantly increased with curing time. Consolidation stress and the percentage of cement were the key parameter of the significant increase in the stress strain behaviour of the marine clay under triaxial test.

\section{Biomass silica treated marine clay}

Kasim et al. (2015) treated marine clay soil obtained from Perak, Malaysia with a chemical additive called Biomass Silica (commercially known as SH-85) in order to have a better strength and engineering characteristics. The treatment was able to increase the strength 6 times from the untreated soil as the amount of additive reached $9 \%$ of the dry weight of soil. Besides, microstructure tests showed that new product was formed as a result of the reaction between the soil and the chemical additive. This new product was in a jelly form and was able to fill the gap between the porous particles of marine clay resulted in a denser and stiffer stabilized soil.

\section{Waste materials treated marine clay}

As mentioned earlier, chemical stabilizers were an effective additives that led to significant increment in the strength and the engineering properties of marine clay. In contrast, researchers nowadays are looking for effective additives that are environmentalfriendly, economical and sustainable. Rao (2013) used polish tile waste to treat the engineering properties of marine clay. Polish tile waste was added to the marine clay in different proportions ranging from 5 to $35 \%$ in an increment of $5 \%$. $15 \%$ was found to be the optimum value at which a noticeable improvement of liquid limit, plasticity index, shrinkage limit, maximum dry density, specific gravity, cohesion and friction angle was observed. In another work by Prasad et al. (2015), rice husk ash was utilized in marine clay as a stabilizing agent. Rice husk ash was added to marine clay in five different proportions; $5,10,15,20$, and $25 \%$. $20 \%$ rice husk ash was the optimum value at which most of the engineering properties were improved such as specific gravity, Atterberg limits, CBR value and compaction parameters.

A waste material produced during the production of zink called gerofix was used by Izabel and Sangeetha (2014) for marine clay improvement. Gerofix was added at 10 to $50 \%$ in an increment of $10 \%$ to marine clay in order to improve its weak engineering characteristics. With regard to strength, $40 \%$ gerofix was the optimum value at which strength was at the highest value. In addition, liquid limit, plastic limit and OMC were decreased while MDD was increased with further increments of gerofix. Moreover, rubber chips (RC) - biomass silica (BS) mixture was implemented by Marto et al (2016) to stabilize marine clay. The percentages of RC - BS were 2-7, and $1-8 \%$, respectively of the dry weight of the soil. The results were compared with another mix of $9 \%$ BS. Results showed that $1 \mathrm{RC}-8$ BS was the optimum value as the strength increased with the increment of BS that acted as a binder that bonded the RC with the marine clay particles. When compared with the control mix (9\% BS), the strength was slightly higher than that obtained from the optimum value of RC - BS. Using rubber chips to stabilize marine clay is cost effective and environmentally-friendly.

\section{CONCLUSION AND RECOMMENDATION}

The review through many research studies on the geotechnical properties of marine clay show that marine clay is a very soft soil that has low strength and high compressibility. Marine clay usually exists in a natural moisture content that is higher than its liquid limit which is the main reason of its weak behaviour. Furthermore, the existence of high percentage of expandable or swellable clay and non-clay minerals increase the weak behaviour of the soil. The organic contents that usually found in marine clay play a significant role due to the existence of swelling clay. Apart from that, due to the weak geotechnical characteristics that marine clay possess, it is recommended to treat marine clay prior to any associated construction. A lot of researchers have used lime, cement, biomass silicate, and waste materials to treat marine clay and cement was found to be the best method of treatment in long curing period. In addition, some studies showed that biomass silicate resulted in a significant increase in the strength which sometimes can reach up to 60 times of the untreated ones. However, it is recommended to use recycled materials as additive that contribute to the strength increment and also environmentally-friendly additives such as recycled tiles, marble dust, granite dust, shredded tyre rubber and plastics.

\section{ACKNOWLEDGEMENT}

This paper was written based on the research carried out using the Research University Grant Scheme (Q.J. 130000.2522.13H85) from Universiti Teknologi Malaysia (UTM). The authors would like to express their gratitude to UTM for their generous support.

\section{REFERENCES}

Ahmad, N. R., Harahap, I. S. H. 2016. The compression behaviour of marine clays in Malaysia. Proceedings of the 35th International Conference on Ocean, Offshore and Arctic Engineering. 1-6.

Ali, F., Al-samaraee, E. A. S. M. 2013. Field behavior and numerical simulation of coastal bund on soft marine clay loaded to failure. Electronic $J$. of Geotech. Eng. 18, 4027-4042.

Arulrajah, A., Bo, M. W. 2008. Characteristics of Singapore marine clay at Changi. Geotech. and Geol. Eng. 26, 431-441.

Azhar, A., Chan, C. M., AbdulKarim, A. T. 2014. Solidification potential of fine-grained dredged marine soils : water-binder ratio effects. J. of Civ. Eng. Res. 4(3A), 48-53.

Basack, S., Purkayastha, R. D. 2009. Engineering properties of marine clays from the eastern coast of India. J. of Eng. Tech. and Res. 1(6), 109-114.

Bo, M. W., Arulrajah, A., Sukmak, P., Horpibulsuk, S. 2015. Mineralogy and geotechnical properties of Singapore marine clay at Changi. Soils and Found. 55(3), 600-613.

Bushra, I., Robinson, R. G. 2010. Strength behaviour of cement stabilised marine clay cured under stress. Proceeding of Indian Geotechnical Conference (GEOtrends), 4-7.

Bushra, I., Robinson, R. G. 2009. Consolidation behaviour of a cement stabilised marine soil. Proceedings of International Geotechnical Conference. 431-434.

Chan, C. 2014. Remoulded dredged marine clay: A study of time factor on strength recovery. Math. Comput. Sci. Ind. 342-347.

Chong, S. Y., Kassim, K. A. 2015. Effect of lime on compaction, strength and consolidation characteristics of Pontian marine clay. Jurnal Teknologi. 72, 41-47.

Egashira, K., Ohtsubo, M. 1982. Smectite in marine quick-clays of Japan. Clays and Clay Miner. 30(4), 275-280.

Izabel, K. J., Sangeetha, S. 2014. Stabilization of marine clay using jerofix. Inter. J. of Sci. Eng. and Res. 4(3), 93-95.

Kang, G., Tsuchida, T., Athapaththu, A. M. R. G. 2016. Engineering behavior of cement-treated marine dredged clay during early and later stages of curing. Eng. Geol.. 209, 163-174.

Kasim, F., Marto, A., Rahman, N. A., Tan, C. S. 2015. Unconfined compressive strength and microstructure of clay soil stabilised with biomass silica. Jurnal Teknologi. 77(11), 9-15.

Kiran, B. M. N., Prasad, D. V. S. 2016. Stabilization of marine clay using ferric chloride and quarry dust. Inter. J. Latest Trends, Eng. Tech. 6(3), 609615.

Lee, P. T., Tan, Y. C., Lim, B. L., Nazir, R. 2016. Some geotechnical properties of Tokai clay. Proceedings of the 19th Southeast Asian Geotechnical Conference. 1-5.

Liu, S. Y., Shao, G. H., Du, Y. J., Cai, G. J. 2011. Depositional and geotechnical properties of marine clays in Lianyungang, China. Eng. Geol. $121,66-74$.

Makusa, G. P. 2013. State of the art review: Soil stabilization methods and materials. Luleå University of Technology, Luleå, Sweden.

Marto, A., Jahidin, M. R., Aziz, A. N. A., Kasim, F. K., Yunus, M. N. 2016. Stabilization of marine clay using biomass silica-rubber chips mixture. Inter. Eng. Res. and Innovation Symp. 160, 1-8.

Marto, A., Yunus, M. N., Pakir, F., Latifi, N., Mat, N. A., Tan, C. S. 2015. Stabilization of marine clay by biomass silica (non-traditional) stabilizers. Appl. Mechanics and Mater. 695, 93-97.

Moses, G. G., Rao, S. N., Rao, P. N. 2003. Undrained strength behaviour of a cemented marine clay under monotonic and cyclic loading. Ocean Eng. 30, 1765-189. 
Oh, E. Y. N., and Chai, G. W. K. 2006. Characterization of marine clay for road embankment design in coastal area. Proceedings of the sixteenth International Offshore and Polar Engineering Conference. 7-10.

Otoko, G. R., Simon, A. I. 2015. Stabilization of a deltaic marine clay (chikoko) with chloride compounds: y-values. Int. Res. J. Eng. Tech. 2(3), 2092-2097.

Otoko, G. R., Blessing, O. C. 2014. Cement and lime stabilization of a Nigerian deltaic marine clay (chikoko). European Inter. J. Sci. Tech. 3(4), 53-60.

Pakir, F., Marto, A., Yunus, M. N., Latifi, N., Tan, C. S. 2014. Effect of sodium silicate as liquid based stabilizer on shear strength of marine clay. Jurnal Teknologi. 76(2), 45-50.

Prasad, D. S. V., Venkatteswarlu, H., Rao, N. J., Kumar, J. C. 2015. Strength behaviour of marine clay treated with rice husk ash. Int. J. Eng. Sci. Res. Tech. 4(5), 561-567.

Rahman, Z. A., Yaacob, W. Z. W., Rahim, S. A., Lihan, T., Idris, W. M. R., Sani, W. N. F. 2013. Geotechnical characterisation of marine clay as potential liner material. Sains Malaysiana. 42(8), 1081-1089.

Rajasekaran, G. 2005. Sulphate attack and ettringite formation in the lime and cement stabilized marine clays. Ocean Eng. 32, 1133-1159.

Rajasekaran, G., Rao, S. N. 2004. Falling cone method to measure the strength of marine clays. Ocean Eng. 31, 1915-1927.

Rajasekaran, G., Rao, S. N. 2002. Compressibility behaviour of lime-treated marine clay. Ocean Eng. 29, 545-559.

Rajasekaran, G., Rao, S. N. 2002. Permeability characteristics of lime treated marine clay. Ocean Eng. 29, 113-127.

Rajasekaran, G., Murali, K., Srinivasaraghavan, R. 1999. Microfabric, chemical and mineralogical study of Indian marine clays. Ocean Eng. 26, 463-483.

Ramamoorthya, S. 2007. Correlation of engineering characteristics of marine clay from central west coast of Malaysia. Master of Engineering, Universiti Teknologi Malaysia, Johor Bahru, Malaysia.

Rao, D. K. 2013. A laboratory investigation on the affect of vitrified polish waste for improving the properties of marine clay. Inter. J. Eng. Innov. Tech 11(2), 37-41.
Rao, D. K., Anusha, M., Pranav, P. R. T., Venkatesh, G. A. 2012. Laboratory study on the stabilization of marine clay using saw dust and lime. Inter. J. Eng. Sci. Adv. Tech. 2(4), 851-62.

Rao, D. K., Raju, G. V. R. P., Babu, K. J. 2011. Field studies on the marine clay foundation soil beds treated with lime, gbfs and reinforcement technique. Inter. J. Eng. Sci. Tech. 3(4), 3105-3112.

Rao, D. K., Raju, G. V. R. P. 2011. Laboratory studies on the properties of stabilized marine clay from Kakinada Sea Coast, India. Inter. J. Eng. Sci. Tech. 3(1), 421-428.

Rao, S. N., and Mathew, P. K. 1996. Permeability studies in marine clays stabilized with lime column. Inter. J. Offshore Polar Eng. 6(3),1-6.

Shahri, Z., Chan, C. 2015. On the characterization of dredged marine soils from Malaysian waters : Physical properties. Environ. Pollut. 4(3), 1-9.

Tanaka, H., Locat, J., Shibuya, S., Soon, T. T., Shiwakoti, D. R. 2001. Characterization of Singapore, Bangkok, and Ariake clays. Canadian Geotech. J. 38(2), 378-400.

Thomas, M., Petry, P. E., Asce, F., Little, D. N., Asce, F. 2002. Review of stabilization of clays and expansive soils in pavements and lightly loaded structures - history, practice, and future. J. Mater. In Civ. Eng. 14(6), 447460.

Tongwei, Z., Xibing, Y., Yongfeng, D., Dingwen, Z., Songyu, L. 2014. Mechanical behaviour and micro-structure of cement-stabilised marine clay with a metakaolin agent. Constr. Build. Mater. 73, 51-57.

Xiao, H. W., Lee, F. H. 2016. Curing time effect on behavior of cement treated marine clay. World Academy Sci., Eng. Tech. 43, 71-78.

Yunus, M. N., Marto, A., Pakir, F., Kasran, K., Azri, M. A., Jusoh, S. N. 2015. Performance of lime-treated marine clay on strength and compressibility chracteristics. Inter. J. Geomate. 8(2), 1232-1238.

Zhang, R. J., Santoso, A. M., Tan, T. S., Phoon, K. K., Asce, F. 2013. Strength of high water-content marine clay stabilized by low amount of cement. $J$. Geotech. Geoenviron. Eng. 139, 2170-2181.

Zillianstetra, V. 2009. Stress - strain behaviour of cement treated marine clay. Geotech. Test. J. 25(4), 1-9. 